\title{
AASB 141 Agriculture: A Deconstruction Using Foucauldian Constructs and Thematic Content Analysis
}

\author{
Gregory Kenneth Laing ${ }^{1}$ \& Ross Kirkham ${ }^{1}$ \\ ${ }^{1}$ Faculty of Arts \& Business, University of the Sunshine Coast, Maroochydore DC, Australia \\ Correspondence: Gregory Kenneth Laing, Faculty of Arts \& Business, University of the Sunshine Coast, \\ Maroochydore DC 4558, Australia. Tel: 61-7-5459-4675. E-mail: glaing@usc.edu.au
}

Received: April 29, 2012 Accepted: May 25, 2012 Online Published: August 17, 2012

doi:10.5539/ass.v8n11p1 URL: http://dx.doi.org/10.5539/ass.v8n11p1

\begin{abstract}
The purpose of this paper is to explore the subtext of the accounting standard AASB 141 Agriculture. A hybrid method is employed in which Foucauldian constructs are examined by way of a thematic construct analysis and a deconstruction to derive an interpretation. The constructs of power are firmly established in the legal authority of the accounting standard with the terminology of the biological asset creating the mechanisim by which to desensitise the exercise of moral judgement. The notion of intellectual property as a legal principle is questioned in light of the view taken by the Courts in the USA and the scientific developments in regards to genetics and biological prodction of artifical life forms. Parallels are drawn between the nature and the context of the standard and the ethical and moral issues that were confronted by individuals during the Third Reich and more recent declines in terms of ethical and moral jusgements in society.
\end{abstract}

Keywords: foucauldian constructs, thematic content analysis, deconstruction, sociology of accounting, AASB 141, biological life forms

\section{Introduction}

Accounting practices are important to the discipline of sociology because the discourse of accounting practices construct the reality within business organisations and indirectly affect other social institutions (Chua 1986: 584; Hines 1991: 317; Jones 1992: 251). Accounting is such a powerful force that there is a need to render visible accounting's wider social significance as a mechanism of social and organisational control (Morgan 1988; Francis 1991; Morgan and Wilmott 1993).

Within the seemingly value-free application of accounting standards there exists a subtext that points to a discourse of control and of discipline (Morgan \& Wlmot, 1993; Miller \& O'Leary, 1987; Hooper \& Pratt, 1993). The significance of accounting as a means of manipulating society was higlighted by the work of Miller and O'Leary (1987) and Hooper and Pratt (1993) their research identified accounting as a process that may best be described as a "mechanism" (Foucault, 1972; 1973; 1980) through which considerable power had been exercised.

History is replete with examples of accounting being used to justify actions which are beyond what would be considered as normal ethical and moral behaviour (Lippman \& Wilson, 2007; Funnell, 1998). Despite this accounting has continued to be practiced in much the same way with little or no thought as to its potential to influence the actions of individuals or groups within society. In recent years, the employees and directors of well-known corporations and international accounting firms have faced criminal charges associated with unethical accounting practices (Wilke, 2002; Clark, Dean \& Oliver, 2003; Hake, 2005).

Accounting practices have the potential to be a powerful mechanism which can shape the financial standing of corporations and as the recent global financial crises has shown even have flow on effects that can influence economies and society (Morgan 1988; Arrington and Francis 1993; Hines 1991). Recent history is replete with examples of financial scandals that have been the result of accounting related issues. From the collapse of the Bearings Bank (Greener, 2006; Brown, 2005), to the sub-prime market manipulation of financial instruments referred to as derivatives that lead to the global financial crisis (Laing, 2011; Frame \& White, 2005) and the various corporate collapses such as Enron, World Com and HIH Insurance (Wilke, 2002; Mak, Deo \& Cooper, 2005; Liu \& Daly, 2011; Ross, 2011). 
Thus in communicating organisational reality, accounting discourse plays a role in constructing the status quo (Hines 1988) and the status quo can impact upon the corporate culture (Francis 1991). Foucauldian constructs offer an opportunity to expose the role of accounting practices in controlling society; an analysis that has been strongly resisted in the accounting literature as a valid means of theorising accounting practice (Hoskin 1994).

\section{Theoretical Framework}

The work of Foucault $(1972 ; 1973 ; 1980)$ provides researchers in the field of sociology with an alternative perspective for examining accounting in context of social interaction (Miller \& O'Leary, 1987; Hooper \& Pratt, 1993). Three recurring themes in the works of Foucault are power, knowledge, and subjectivity (Foucault 1980). Accounting has been described as a 'social construct' (Hines, 1988) or a metaphorical language constructing reality (Walters-York 1996). Thus accounting may be viewed as constituting what Foucault (1980) referred to as a 'mechanism' for the exercise of power.

The intention in this paper is to challenge the primacy of the origins and presumed truths in order to facilitate alternative explanations and expose potential new truths that may exist in the subtext of the narrative.

\section{Method}

The method employed in this paper is a hybrid methodology which combines the Foucauldian constructs, of accounting as a mechanism of power, with the thematic content analysis of the language which is then deconstructed to interpret the subtext. This hybrid method provides a basis for the interpretation of the text in order to derive meaning from the unfamiliar (Boland, 1991) and to assist in the identification of the symbolic meaning in the subtext of the communication (Ricoeur, 1980). The thematic content anlysis provides the intial identification of the subtext embedded in the language of the accounting standard (Pennebaker \& King, 1999; Amac, 1997; Oxman, Stanley, Rosenberg, Schnurr \& Tucker, 1988). Thematic analysis is concerned with the identification of the themes emerging from the text that are consistent with the framework derived from the Foucauldian construct. Assumptions about the meaning embedded within the text are then subjected to interpretation through the lens of deconstruction (Duncan, 1994). Deconstruction explores the themes in the language that carry with them subtexts (Norris, 1982) and this method was used by Arrington and Francis (1989) to identify themes inherent in accounting discourse. Consistent with the work of Arrington and Francis (1989) the level of subtext is considered to be related to the hidden or supressed meanings derived from the language being used in the accounting standard. To that end the interpretation of the subtext level is more concerned with levels of meaning that may otherwise not be readily obvious to a reader.

This hybrid methodology benefits from the substantive literature that supports the use of each of these methods. In terms of the accounting standard, written text is considered to be a convenient form of presenting semantic information and this is especially so in the case of an accounting standard which follows a very set format for the presentation of the rules and guidance for its implementation. The analysis of the text followed the recommendations of Strauss and Corbin (1990) in conjunction with the suggestions of Gephart (1993). The first step was to identify subtext indicators that would form the basis of the list of words that coincide with the Foucauldian constructs of power and a relevant mechanism. The next step was to determine the frequency with which these terms occurred and then apply the interpretation.

\section{Thematic Content}

There are words and terms which are used extensively and they are indicative of the way in which the standard establishes itself as a mechanism of power. The terms which were identified as predominant in the text are:

Asset - a resource owned and controlled as a result of past events that has probable future economic benefits - this term occurs 12 times in the text.

Agricultral activity - the management of the biological transformation of biological assets - this term occurs 11 times in the text.

Agricultural produce - the harvested product of a biological asset - this term occurs 25 times in the text.

Bilogical asset - a living animal or plant - this term occurs 85 times in the text.

Harvest - the detachment of produce from a biological asset or the cessation of a biological asset's life process reference to this term occurs 20 times in the text.

There are other terms which were identified in the process of the content analysis and that have relevance to the interpretation process that is to follow. These terms are: animals - which occures 4 times in the text; plants - which occurs 4 times in the text; living - which occurs 4 times in the text; biological transformation - which occurs 8 times in the text; agricultural produce - which occurs 25 times in the text; entity - which occurs 29 times in the text; and government grants - which occurs 21 times in the text. 
The predominance of these terms reinforces the notion that the standard is dealing with inanimate objects which are reduced to the lowest common denominator - that of a mere asset belonging to the entity.

\section{Background to AASB 141 "Agriculture"}

The accounting standard (AASB 141 "Agriculture") has the force of law as it is enshirined under the Corporations Act of Australia. From this position it meets the Foucauldian construct of a mechanism of power to be exercised and obeyed as it is enshrined in the legal context. The accounting standard AASB 141 "Agriculture" was introduced in July 2004 and replaced the original standard AASB 1037 Self-generating and Regenerating Assets. The change in title and number occurred as a result of the Australian Accounting Standards Board adopting the International Accounting Standards. AASB 141 is in fact based on the International Accounting Standard IAS 41. The basic coverage remains the same in so far as the standard seeks to cover the treatment of what is referred to as biological assets and agricultural produce - up to the point of harvest.

The history of the standard can be traced back to the original Exposure Draft (ED 83) and this was the subject of strong arguments emanating from the Group of 100 companies and their representatives (Denison, 1999). As the most prominent of the lobby groups they used their political power to exert influence at a critical stage in the development of the standard. In fact the notes included in the standard when it was first promulgated in 1998 revealed that several significant concessions had been made. Even as far back as 1998 the Group of 100 had sent a letter to Sir Brian Carsberg the then Secretary of the international Accounting Standards Board expressing their concerns with regards to the measurement of market values and warning of problems for implementation at an international level (Denison, 1999). Thus, even before the standard had been fully considered at the international level there had been attempts to subvert the possible directions that an international standard might take. The potential to use the accounting standard to obscure the actions of the large corporations can therefore not be underestimated.

\section{Deconstruction}

The notion that an accounting standard expressly covers living animals and plants is a matter of concern given the debate raging around the legal rights of artificial life (Hettinger, 1995; Bagley, 2004; Jasanoff, 2002) which includes biologically developed components that would legally be the property of the company that holds the patent. The California Supreme Court in July 1990 ruled that the cancer cells taken from a patient by a doctor were the property of the doctor not the patient and that the biological development ascertained from those cells were therefore legally subject to a patent (Hylton, 2001). This is something that surely must point to the lessons from the past and the issues of ethical and moral judgement that would seem to be far more complex than this accounting standard could possibly have meant to cover. There is little doubt that the intention of the accounting standard was and arguably continues to be focused on the treatment of assets such as crops, forests, livestock, acquaculture, and living assets created by biotechnology.

The manner in which the language in the standard deals with living assets raises concern because the text may well encompass human embryos, human zygots and potentially any form of human stem cells (Bagley, 2004; Phillips, 2004). Whilst this is a possibility it was initially claimed that these were not intended to be covered under the standard (Keys, 1997, 1998). However, that was before the emergence of the use of human stem cells as a possible cure for cancer and the potential benefits for the treatment of other forms of disability (Singh et al, 2003). Perhaps that may be the reason that the title of the accounting standard was changed from the original form of "Self-Generating and Regenerating Assets" to the less evocative terminology of "Agriculture". No explanation is given in regards to this change.

In the mean time firms such as Monsanto, Novartis, Dupont and Hoechst Chemical have all been moving into genetic research and genetic-based technologies and products, in preparation for the new age of genetic commerce (Galambos \& Sturchio, 1998; Riffkin, 1998). These companies are preparing for the situation where they hope to achieve a mass-production of cloned animals for a range of commercial purposes, including medical research, the harvesting of organs for transplants and to produce designer genes artificially introduced into their genetic makeup, turning them into chemical factories for cheap and abundant pharmaceutical and chemical products (Galambos \& Sturchio, 1998; Rifkin, 1998).

The ethical issues have been overlooked by the patent laws in most countries around the globe, in particular the USA (Bagley, 2004; Hettinger, 1995) where the courts have backed the pharmaceutical companies (Kershen, 2004; Sandel, 2004; Hylton, 2001) and of particular concern their rulings of liability against individuals who are the victims of nature breaching the patent (Lee \& Burrell, 2002). The corporate culture seems to be one of enforce the legal patent right at every possible opportunity and this attidtude seem to have been given a boost by the legal rulings eminating from the US courts. The corporate culture, which seems to be bordering on greed, is vindicated by the legal outcomes 
and continues to influence the unethical decisions to seek to prosecute all and sundry - certainly an example of the corportae culture being tied to the ethical and moral judgements being made by the corporations (Puttee, Vitale \& Laing, 2011). If indeed as claimed in the literature (Boddy, 2006; Gudmundsson \& Southey, 2011) there are psychopaths lurking in the board rooms of corporations then there must be a very real concern that history could well be repeated (Lippman \& Wilson, 2007; Funnell, 1998) especially where the mechanism exists for the individuals to feel justified in that they were merely following the lawful orders (Littell, 2009). The accounting standard having the force of law is a prime example of such a mechanism whereby individuals may feel that they have done nothing wrong. The use of language to obscure the reality of the situation may be aligned with the attempts to make the whole concept, of dealing with life forms, more appealing to society in general after all this is a ploy that has been used successfully throughout the history of the world (Littell, 2009; Lippman \& Wilson, 2007; Funnell, 1998).

Pharmaceutical companies are already using human genetic material to grow human tissue using animals. For example, human ears are being grown on rats and pigs are being used to grow genetically modified liver, kidney and heart tissue for transplantation to humans (Sandel, 2004; Singh, Clarke, Terasaki, Bonn, Hawkins, Squire, \& Dirks, 2003). So in the future the possibilities are potentially limitless. Indeed the first test tube baby lead to the present situation in medicine where human eggs can be harvested and used to assist couples to produce children. Certainly that would hardly warrant concern or attention from the perspective of ownership since a child born of human parents would certainly be deemed to have all the rights afforded in society to any other child. However, science is advancing at such an exponential rate that things which were previously thought impossible are becoming possible (Phillips, 2004; Bagley, 2004).

The possibility that human life could be created that would be owned by a pharmaceutical company is a feasible and conceivable proposition (Bagley, 2004; Hettinger, 1995). This relies on the understanding that within the strict interpretation of law, as it presently exists, there would be a strong case for recognition of ownership under the law (Jasanoff, 2002). Then to provide a form of reinforced justification for the manner in which to account for such a situation AASB 141 would provide the corporation with the means for recording the 'asset' in much the same way as any other asset owned by the company. Specifically, the company would be able to demonstrate that it has legal ownership of the biological asset which was produced in accordance with a registered patent and that there was an expectation of future economic benefits to be derived from the exclusive use of the asset - all of these would satisfy the key requirements under the standard. The end result would be that from the perspective of AASB 141 the asset would be treated in the same way as any other 'agricultural' asset. This process is consistent with the legal process that was used to affect a compliant society by the Third Reich - legitimising the treatment of other human beings as 'mere units of production' devoid of any human attributes (Funnell, 1998). The concept of society's acting in an inhuman way to other members of society is not limitited to the Third Reich but has occurred in more recent times making names such as Kosovo and Pol Pot just as infamous (Harff \& Gurr, 1989; Freeman, 2008).

The argument that individuals may lack empathy is coincidentally aligned with the trait that has been identified as distinguishing the psychopath from the rest of society (Boddy, 2006 ; Guddmundson \& Southey, 2011). The possibility that an innocuous accounting standard could be used in such a manner may seem fanciful in the extreme but as history has shown even the most unethical and corrupt practices can occur and therefore have to be considered. The Milgram (1967) experiments provided evidence that any member of society could be induced into undertaking activities that would otherwise be considered as too cruel and inhumane to be inflicted on other humanbeings. The experiment provided strong evidence of the existence of obedience to authority - a situation which is analogous with the authority and power emanating from the accounting standard.

\section{Conclusion}

The analysis and interpretation provide an opportunity for sociologists to glean some insight into the part that accounting standards can play in the control over moral judgements in the world of business and society in general. Accounting standards have the force of law and through that position they possess the power to absolve individuals from any feelings of remorse or moral judgement. The language obscures the subtext and makes the moral judgements seem to be normal actions dissasocitated from the reality of the events.

\section{References}

AASB 1037. (1998). Self-Generating and Regenerating Assets. Australian Accounting Research Foundation: Australia.

AASB 141. (2012). Agriculture. Australian Accounting Standards Board: Australia.

Arrington, C. E., \& Francis, J. R. (1989). Letting the Chat out of the bag: Deconstruction, Privilege and Accounting $\begin{array}{llll}\text { Research. } & \text { Accounting, }\end{array}$ 
http://dx.doi.org/10.1016/0361-3682(89)90030-5

Arrington, C., \& Francis, J. (1993). Giving Economic Accounts: Accounting as Cultural Practice. Accounting, Organizations and Society, 18(2-3), 107-124. http://dx.doi.org/10.1016/0361-3682(93)90029-6

Bagley, M. (2004). Stem Cells, Cloning and Patents: What's Morality Got to Do with it? New England Law Review, 39, 501-509.

Boddy, C. R. (2006). The dark side of management decisions: Organisational psychopaths. Management Decision, 44(9-10), 1461-1475. http://dx.doi.org/10.1108/00251740610715759

Brown, A. D. (2005). Making Sense of the collapse of Barings Bank. Human Relations, 58(12), 1579-1603. http://dx.doi.org/10.1177/0018726705061433

Chua, W. (1988). Interpretive Sociology and Management Accounting Research. Accounting, Auditing and Accountability Journal, 1(2), 59-79. http://dx.doi.org/10.1108/EUM0000000004624

Clarke, F., Dean, G., \& Oliver, K. (2003). Corporate Collapse - Accounting, Regulatory and Ethical Failure (2nd ed.). Cambridge University Press: Cambridge.

Denison, B. (1999). Agriculture. Retrieved from http://www.group100.com.au/submissions/sub_aasb1037_19990525

Denison, B. (1999). Accounting for Self-Generating and Regenerating Assets. Retrieved from http://www.group100.com.au/submissions/sub_aasb1037_19990504

Dreyfus H., \& Rabinow P. (1982). Michel Foucault: Beyond Structuralism and Hermeneutics. Harvester Wheatsheaf: New York.

Duncan, S. (1994). Law as literature: Deconstructing the legal text. Law and Critique, 5(1), 3-29. http://dx.doi.org/10.1007/BF01129728

Foucault M. (1972). The Archaeology of Knowledge. Random House: New York.

Foucault M. (1973). The Order of Things: The Archaeology of the Human Sciences. Vintage Books: New York.

Foucault M. (1980). Power/Knowledge: Selected Interviews and Other Writings. Pantheon: New York.

Frame, W., \& White, L. (2005). Fussing and Fuming over Fannie and Freddie: How Much Smoke, How Much Fire? Journal of Economic Perspectives, 19(2), 159-184. http://dx.doi.org/10.1257/0895330054048687

Francis, J. (1991). After Virtue: Accounting as a Moral and Discursive Practice. Accounting, Auditing and Accountability Journal, 4(1), 5-17.

Freeman, M. (2008). Speaking about the Unspeakable: genocide and philosophy. Journal of Applied Philosophy, 8(1), 3-18.

Funnell W. (1998). Accounting in the Service of the Holocaust. Critical Perspectives on Accounting, 9(4), 435-464. http://dx.doi.org/10.1006/cpac.1997.0164

Galambos, L., \& Sturchio, J. (1998). Pharmaceutical firms and the transition to biotechnology: A study in strategic innovation. Business History Review, 72(2), 250-278. http://dx.doi.org/10.2307/3116278

Gephart, R. (1993). The textual approach: Risk and blame in disaster sense-making. Academy of Management Journal, 36(X), 1465-1514. http://dx.doi.org/10.2307/256819

Greener, I. (2006). Nick Leeson and the Collapse of Barings Bank: Socio-Technical Networks and the 'Rogue Trader'. Organization, 13(3), 421-441. http://dx.doi.org/10.1177/1350508406063491

Guddmundson, A., \& Southey, G. (2011). Leadership and the rise of the corporate psychopath: What can business schools do about the 'snakes inside'? E-Journal of Social \& Behavioural Research in Business, 2(2), 18-27.

Hake, E. R. (2005). Financial Illusion: Accounting for Profits in an Enron World. Journal of Economic Issues, 39(3), 595-611.

Harff, B., \& Gurr, T. (1989). Victims of the State Genocides, Politicides, and Group Repression Since 1945. International Review of Victomology, 1(1), 23-41.

Hettinger, N. (1995). Patenting Life: Biotechnology, Intellectual Property, and Environmental Ethics. Boston Coll. Environ. Affairs Law Review, 22(Winter), 267-305.

Hines, R. (1988). Financial Accounting: In Communicating Reality, We Construct Reality. Accounting, Organizations and Society, 13(3), 251-261. http://dx.doi.org/10.1016/0361-3682(88)90003-7

Hines, R. (1989). The Sociopolitical Paradigm in Financial Accounting Research. Accounting, Auditing and 
Accountability Journal, 2(1), 52-76. http://dx.doi.org/10.1108/09513578910134671

Hooper K., \& Pratt M. (1993). The Growth of Agricultural Capitalism and the Power of Accounting: A New Zealand Study. Critical Perspectives on Accounting, 4, 247-274. http://dx.doi.org/10.1006/cpac.1993.1015

Hopwood, A. (1987). The Archaeology of Accounting. Accounting, Organizations and Society, 12(3), 207-234. http://dx.doi.org/10.1016/0361-3682(87)90038-9

House R. (1988). Power and Personality in Complex Organisations. Research in Organisational Behavior, 10, 305-357.

Hylton, W. S. (2001). Who owns this body? Esquire, 135(6), 103-111.

Jasanoff, S. (2002). The life sciences and the rule of law. Journal of Molecular Biology, 319, 891-899. http://dx.doi.org/10.1016/S0022-2836(02)00337-6

Jones, T. (1992). Understanding Management Accountants: The Rationality of Social Action. Critical Perspectives in Accounting, 3, 225-257. http://dx.doi.org/10.1016/1045-2354(92)90003-A

Kershen, D. (2004). Legal Liability Issues in Agricultural Biotechnology. Crop Science, 44(2), 456-463. http://dx.doi.org/10.2135/cropsci2004.4560

Keys, R. (1997, November). Closer look at living assets. Australian Accountant.

Keys, R. (1998, October). Live Assets. Charter.

Laing, G. (2011). The Sixth Kondratieff Cycle the Era of Financial Market Instruments: A Reflection on the Australia vs US Subprime Mortgage Market. International Journal of Economics and Finance, 3(5), 37-41. http://dx.doi.org/10.5539/ijef.v3n5p37

Lee, D., \& Newby, H. (1983). The Problem of Sociology. Unwin Hyman: London.

Lee, M., \& Burrell, R. (2002). Liability for the Escape of GM Seeds: Pursuing the 'Victim'? The Modern Law Review, 65(4), 517-537. http://dx.doi.org/10.1111/1468-2230.00393

Lehman C., \& Tinker T. (1987). The "Real" Cultural Significance of Accounts. Accounting, Organizations and Society, 12(5), 503-522. http://dx.doi.org/10.1016/0361-3682(87)90033-X

Lippman, E., \& Wilson, P. (2007). The culpability of accounting in perpetuating the Holocaust. Accounting History, 12(3), 283-303. http://dx.doi.org/10.1177/1032373207079028

Littell, J. (2009). The Kindly Ones. Chatto \& Windus: London.

Liu, Y., \& Daly, K. (2011). Australia and US House Price Affordability 1980 - 2009. Journal of New Business Ideas \& Trends, 9(2), 11-22.

Mak, T., Deo, H., \& Cooper, K. (2005). Australia's major Corporate Collapse: Health International Holdings (HIH) Insurance "May The Force Be With You". Journal of American Academy of Business, 6(2), 104-112.

Manicas P. (1993). Accounting as a Human Science. Accounting, Organizations and Society, 18, 147-161. http://dx.doi.org/10.1016/0361-3682(93)90031-Z

McNay L. (1994). Foucault: A Critical Introduction. Polity Press: Cambridge.

Milgram, S. (1967). The Small World Problem. Psychology Today, 1(1), 60-67.

Miller P., \& O'Leary T. (1987). Accounting and the Construction of the Governable Person. Accounting, Organizations and Society, 12(3), 235-264. http://dx.doi.org/10.1016/0361-3682(87)90039-0

Morgan, G., \& Willmott, H. (1993). The "New" Accounting Research: On Making Accounting More Visible. Accounting, Auditing and Accountability Journal, 6(1), 3-36.

Norris, C. (1988). Deconstruction: Theory and Practice. Methuen \& Co.: New York.

Pfeffer, J. (1981). Power in Organizations. Pittman: Marshfield.

Phillips, V. (2004). Half-Human Creatures, Plants \& Indigenous Peoples: Musings on Ramifications of Western Notions of Intellectual Property and the Newman-Rifkin Attempt to Patent a Theoretical Half-Human Creature. Santa Clara Computer \& High Tech Law Journal.

Puttee, C., Vitale C., \& Laing, G. (2011). Eight Dialogues on Business Ethics: Aspects of Ethical Behaviour in the Corporate Sector. E-Journal of Social \& Behavioural Research in Business, 2(2), 1-17.

Rifkin, J. (1998, August 11). The mice that roar the future: The rush to patent, clone and mass- produce animals may 
be a precursor of the way humans are produced someday. The Ottawa Citizen [Ottawa, Ont].

Ross, S. (2011). A Model for Examining Foreign Direct Investment in Real Estate. Journal of New Business Ideas \& Trends, 9(2), 23-33.

Salancik G., \& Pfeffer J. (1974). The Bases and Uses of Power in Organizational Decision Making: The Case of a University. Administrative Science Quarterly, 25, 1-17.

Sandel, M. J. (2004). Embryo Ethics - The Moral Logic of Stem-Cell Research. The New England Journal of Medicine, 351(3), 207-209. http://dx.doi.org/10.1056/NEJMp048145

Singh, S., Clarke, I., Terasaki,M., Bonn, V., Hawkins, C., Squire, J., \& Dirks, P. (2003). Identification of a Cancer Stem Cell in Human Brain Tumors. Cancer Research, 63(18), 5821-5828.

Strauss, A., \& Corbin, J. (1990). Basics of Qualitative research: Grounded Theory Procedures and Techniques. Sage: Newbury Park, CA.

Tyson, T. (1993). Keeping the Record Straight: Foucauldian Revisionism and Nineteenth Century US Cost Accounting History. Accounting, Auditing and Accountability Journal, 6(2), 4-16. http://dx.doi.org/10.1108/09513579310036341

Walters-York, L. (1996). Metaphor in Accounting Discourse. Accounting, Auditing and Accountability Journal, 9(5), 45-70. http://dx.doi.org/10.1108/09513579610367242

West, B. (1998). Exploring Professional Knowledge: The Case of Accounting. Journal of Sociology, 34(1), 1-21. http://dx.doi.org/10.1177/144078339803400102

Wilke, J. R. (2002, April 9). Andersen Ex-Partner to Plead Guilty --- Fired for Shredding Files On Enron, Duncan Agrees To Cooperate. The Wall Street Journal, p. A3.

Willmott, H., Puxty, T., \& Sikka, P. (1993). Losing One's Reason: On the Integrity of Accounting Academics. Accounting, Auditing and Accountability Journal, 6(2), 98-110. http://dx.doi.org/10.1108/09513579310036404 